\title{
THE BARCELONA DISPUTATION: TEXTS AND CONTEXTS
}

\author{
NinA CAPUTO* \\ University of California, Berkeley
}

\begin{abstract}
Scholars of Jewish history have paid consistent and devoted attention to the Barcelona Disputation of 1263. Records of this event preserve contemporary Jewish and Christian responses to the proceedings, which pitted Nahmanides, the most important exegete and teacher of the region, against a convert from Judaism to Christianity, took place in the royal court before an illustrious audience. This essay traces trends in scholarly treatments of the Barcelona Disputation from the early days of the Wissenschaft des Judentums to the present. By examining challenges of veracity posed by the documentary sources as well as foundational assumptions about what the medieval authors intended to achieve with their accounts, this article provides broad overview of the historiography that has developed around the Barcelona Disputation.
\end{abstract}

KEYWORDS: Nahmanides, Barcelona Disputation, polemics, historiography

\begin{abstract}
'Has anyone ever seen a new idea come out of a polemic? And how could it be otherwise, given that here the interlocutors are incited not to advance, not to take more and more risks in what they say, but to fall back continually on the rights that they claim, on their legitimacy, which they must defend, and on the affirmation of their innocence?'
\end{abstract}

Michel Foucault

It is an irony of the historical record that though abundant documentary evidence of the medieval theological controversy between Christianity and Judaism remains, it is decidedly difficult to reconstruct the tone, level of candor, and content of face to face encounters. This is true even in the case of the officially sponsored public disputation in Barcelona, which is recorded in several widely-studied documents. The story is by now fairly well known. In the summer of 1263, Nahmanides, perhaps the most well respected Jewish teacher, scholar, and leader in Catalonia, was summoned by King James I of Aragon to participate in a theological debate with a certain

* NINA CAPUTO (PhD 1999, University of California, Berkeley) is Associate Professor at the Department of History, University of Florida, Gainesville. 
Dominican friar named Paul at the Royal Palace in Barcelona. [Nahmanides transliterates his name as Pul in Hebrew, whereas most of the English scholarship refers to him as Friar Paul, Paulo, or Pablo Christiani. In this paper all of the names will be anglicized for consistency.] Paul had converted from Judaism to Christianity and brought with him some knowledge of rabbinic teachings and scholarship. Many of the friar's claims fell within the purview of traditional polemical arguments against Judaism. The Christian supersessionist claim that Jesus fulfilled the messianic redemption prophesied for the Benei Israel in the Hebrew Bible had been a mainstay of Christian polemic since late antiquity. But Friar Paul also brought an argument that can be legitimately classified as new. He wished to demonstrate through evidence drawn from the Talmud that the Jewish sages recognized that Jesus was the messiah. Use of the Talmud in polemical debate was, of course, not in itself completely innovative. At the Paris disputation of 1240, the Christian disputant, Nicolas Donin, also a convert who brought some familiarity with rabbinic sources, argued that Jews' adherence to laws advanced in the Talmud, a text he claimed was rife with blasphemous statements, diverted Jews from true biblical Judaism. What was new in Paul's tactic was the recognition of Talmudic sources as authoritative because they could demonstrate the truth of Christianity.

Though relatively substantial documentary evidence remains from the public disputation in Barcelona (1263), the highly-stylized nature of the texts has rendered the encounters frustratingly-or perhaps enticinglyopaque. ${ }^{1}$ Barcelona Disputation has thus long occupied a privileged place in modern reconstructions of the medieval Jewish past. Records of this event have been preserved in two detailed documents: one in Latin, representing the Christian perspective, and the other in Hebrew, representing the Jewish perspective. The former, likely written by Friar Paul, is little more than a protocol of subjects discussed, annotated with derisive assessments of Nahmanides' arguments. The Hebrew text, written in the style of a firsthand recollection by Nahmanides, provides an exhaustive account of the

1 The documentary record related to the Paris Disputation of 1240 poses the same kinds of challenges, though amplified for a variety of reasons. Hebrew report of this disputation was not written by a witness to the event. Indeed, recent research by Harvey Haims suggests that the document that is commonly read as an account of the disputation of 1240 was in fact composed in the wake of a later disputation in Paris and that the author was familiar with Nahmanides' disputation account. Hames HJ (2015) Reconstructing Thirteenth-Century Jewish-Christian Polemic: From Paris 1240 to Barcelona 1263 and Back Again. In Szpiech R (ed) Medieval Exegesis and Religious Difference: Commentary, Conflict, and Community in the Premodern Mediterranean. New York, NY: Fordham University Press, pp. 115-27. The documents related to this event can be found in an English translation in Friedman J et al. (2012) The Trial of the Talmud: Paris, 1240. Toronto: Pontifical Institute of Mediaeval Studies. 
debate in a dialog form that claims to replicate the structure and content of the discussion. The Hebrew and Latin accounts both indicate that the Barcelona Disputation provided the Dominican friars an opportunity to apply a new missionizing strategy that utilized the Talmud to demonstrate that the rabbis recognized Jesus as the messiah promised by the Hebrew prophets.

While both accounts agree about the basic points of discussion, they differ greatly in perspective. As would be expected, both authors assume a decidedly partisan narrative voice, debasing the opposing side and amplifying their own rhetorical prowess. Immediately following the disputation and at the urging of the friars, the crown issued a series of orders pertaining to the Jewish communities in the Crown of Aragon, some obliging Jews throughout the realm to attend sermons and others censoring Jewish books (Denifle 1887: 234-36). However, Jewish leaders soon succeeded in persuading the king to scale these regulations back so that Jews were no longer obliged to attend sermons in the public square (Denifle 1887: 287).

A controversy arose over textual records of in the disputation in 1265 . Upon learning that Nahmanides had composed an account of his experience during the disputation, which he then gave to the bishop of Girona, the friars made an official complaint to King James accusing the rabbi of having fabricated details in his report. They also charged that he filled his narrative with blasphemy. As punishment, the king ordered that the book be burnt and that Nahmanides be exiled from the Crown of Aragon for a period of two years (Denifle 1887: 239-240). Viewing this punishment as too lenient, the Dominicans appealed to the pope to mandate a penalty of permanent exile. He replied with an eloquent rejoinder reprimanding the king and calling for a more decisive punishment of Nahmanides (Denifle 1887 240-243). Though the documentary trail goes silent after the pope's condemnation of Nahmanides, it is well known that the rabbi relocated to the Land of Israel, where he later died.

Nahmanides composed his detailed linear narrative account of the encounter some two years following the disputation. There is some indication that he may have written this work in the Catalan vernacular at the behest of the bishop on Girona, but the version that comes to us today is written in Hebrew (Denifle 1887: 239). This text is distinctive in the corpus of medieval polemical literature. In contrast with the Hebrew account of the disputation in Paris, which presents each of the actors as caricatures, Nahmanides drew all of the disputation participants as distinct characters, with individual motives, who express fully developed thoughts. And unlike the author of the Latin protocol, Nahmanides' crafted a complete narrative with a clearly delineated beginning, middle, and end that presents the disputation as a dynamic exchange in which dramatic tensions arose and were resolved. But perhaps most significantly, the Hebrew account presents a first person per- 
spective of the debate. As Yosef Yerushalmi has argued, sequential historical narratives of recent events were rare in the pre-modern Jewish world (Yerushalmi 1989: especially 31-52). Authors who chose this genre frequently did so in the wake traumatic events as a strategy for fitting historical challenges to Jewish chosenness into a historical understanding that sees God as an active force directing human history. The fact that Nahmanides left no explicit testimony about what inspired him to compose this account of the disputation has driven a good deal of debate about what he hoped it might accomplish and what kind of audience it was intended for.

Medieval public disputations were necessarily conducted in an atmosphere tinged with adversity and discord. And the authors of documents recounting them intended to reproduce, or at the very least to recall, the deep tension that gave the discussion gravity in the first place. But this is just part of the picture. Disputations could be successful only if sufficient common ground existed between the two sides to enable a clear expression of the difference between the disputants' interpretations. In terms of the language in which the debate took place, this is merely a statement of the obvious. But at the level of politics, culture, and religion, the points of intersection and divergence are more fundamental and also more difficult to pin down. In the controlled atmosphere of a public disputation, issues that were not likely the stuff of everyday discussion either among Jews or between Jews and their Christian neighbors were explicitly addressed. And since victory in a debate with an opponent who was either mute or incompetent was no victory at all, each party needed to present his arguments in a manner that would elicit discussion and response from his adversary. The process of building rhetorical boundaries between Judaism and Christianity, therefore, might also have had the unexpected and perhaps contradictory result of reaffirming the points of contact between the two traditions. The same general considerations apply to the production of textual records or narrative representations of such debates. It can be taken as a given that no medieval religious disputation account is devoid of partisan biases.

In this essay, I will examine the traditions of scholarship that have emerged around the texts, content, and context of the Barcelona disputation of 1263. The disputation has, of course, generated a very large-and still growing-body of secondary scholarship. This can be attributed to the relatively substantial body of documentation related to the disputation. However, the prominent cast of characters who participated in the disputation also made this event enormously interesting to historians of medieval Jewry. Nahmanides himself was a highly influential leader in the Jewish community of Aragon. His exegesis, which was the first to apply the mystical teachings of kabbalah in a relatively open and forthright manner, attracted a wide circle of students and his legal interpretations (tshuvot) were 
highly regarded throughout the Jewish world. The Hebrew disputation account echoes and amplifies some arguments expressed in his exegesis, but it also expresses views that some scholars believe to be directly at odds with the Nahmanides they encounter in mystical exegesis and legal findings.

The competing Hebrew and Latin accounts of the disputation similarly complicate modern views of King James I of Aragon. Nahmanides represents the king as a fair and compassionate patron and judge of the disputation proceedings, who went so far as to reward the rabbi for his performance in the disputation (Chavel 1964: 320). The Latin account, on the other hand, is virtually silent about the king's role in the event. This inconsistency between the documents raises questions about the veracity of the evidence itself and about the king's position on Jewish politics more generally. Jewish historians have long lauded James as a relatively benevolent ruler who, because he benefitted from his Jewish subjects' economic ventures and leadership abilities, protected the Jews' religious liberties in the Crown of Aragon (Assis 1997:19-34). His compliance with pressure from the pope and the friars to sponsor this disputation and his subsequent support of forced sermons and censorship of Jewish books, however, seem to demand a more nuanced and deeply contextualized frame of analysis.

It bears noting that the way modern scholars have interpreted the disputation and the textual evidence related to it provides an important illustration of some of the challenges scholars of medieval Jewish history face in weighing and interpreted their sources. More precisely, assumptions about the limits of Jewish power or powerlessness in the context of Christian society shape the way modern readers conceptualize the power and agency of historical actors and authors of textual evidence of the period. The Hebrew account of the Barcelona disputation poses particular challenges. Nahmanides used the authorial 'I' throughout the disputation account; in addition, he explicitly stated that 'This is an account of all of the disputations. To my knowledge, I did not change a word' (Chavel 1964: volume 1, 319). However, differences in style and perspective between the Hebrew and Latin documents, together with the implicit suggestion in the Hebrew document that Christian authorities permitted Nahmanides to behave as if he and his Christian interlocutors were on a level playing field, and the abundant detail of the account simultaneously have forced modern scholars to grapple with the uncomfortable possibility that the account was significantly embellished by its author. Questioning Nahmanides' claim that he provided a true and accurate report of the disputation might be perceived as tantamount to stating that he consciously and intentionally lied to his reader. If his fitness as a reporter of historical events could be legitimately impugned, then might not his character as a leader, legal authority, and interpreter of texts also come into question? 
The dominant scholarship on the Barcelona disputation revolves around two central axes. The first grapples with questions emerging from the relationship between the two disputation accounts, on the one hand, and the question of whether the textual accounts of the event correspond with the debate as it unfolded, on the other. Did a real debate or exchange of any kind take place at all, or were the texts constructed to represent the event as the authors would have liked it to have transpired? If the texts do not represent a faithful and fully accurate report of the events as they took place, what can we glean from them about Jewish-Christian relations, medieval Jewish perceptions of community, or the significance of Jewish-Christian dialogue? The second chain of analysis considers how the Barcelona disputation fits into the broader history of Christian anti-Jewish polemics. At issue here are questions about transformations in the way Christians viewed and engaged with Jews and Judaism, the way that Jews responded to changing tactics on the part of the clergy, and the practical consequences of increased theological scrutiny of Jewish communities.

\section{Truth and Consequences}

From the early days of the Wissenschaft des Judentums, historians interested in the relationship between the crown, the church, and the Jews have viewed the Barcelona Disputation as a decisive turn in the history of JewishChristian relations and increasing Christian scrutiny of Jewish behavior and texts. Consequently, the early scholarship on the disputation echoed the emotional and polemical tone at the core of the disputation itself. In 1865, responding to claims by the seventeenth-century Christian editor of both disputation accounts that Nahmanides intentionally lied about the content and outcome of the disputation, Heinrich Graetz published an article in which he accepted at face value Nahmanides' successful and masterful refutation of the friars' arguments as depicted in the Hebrew disputation narrative (Wagenseil 1681; Graetz 1865). Writing at a time when Jewish history as a discipline was deeply rooted in the work of building and fortifying Jewish institutions and traditions in Germany, Graetz believed that prominent Jews throughout history acted primarily as Jews in a world that, often as not, placed significant impediments before them. His analysis largely focused on the incommensurability between the Latin and Hebrew accounts in terms of style and content. Graetz thus used his examination of the disputation documents as an opportunity to suggest that powerful men in Latin Christendom, and in the Church in particular, routinely falsified the historical record pertaining to Jewish-Christian relations during the middle ages. Nahmanides, in Graetz's view, defended Judaism heroically and, though he had been cornered by a considerably more powerful opponent, he successfully put his adversary to shame. His categorical acceptance of the Hebrew 
disputation account as true and correct was rooted in his assessment that the Latin report was born of humiliation and was intended to deceive its reader about the outcome of the debate.

Graetz's conception and practice of Jewish history in general drew criticism from some of the most prominent Jewish historians of the time, who felt that his work defaulted too easily to the celebratory and veered away from critical analysis. However, his article on the Barcelona disputation drew its most outspoken criticism from Heinrich Denifle, a prominent historian of medieval theology (Denifle 1887). Himself a Dominican and a Vatican archivist who, over the course of his career, wrote substantial works on Thomas Aquinas, the history of the University of Paris, medieval mysticism, and Luther, Denifle took issue with the thrust of Graetz's argument and with some of the foundational assumptions about his sources and the conclusions he drew from them. Denifle also took issue with Graetz's argument about the identity of the individual referenced in the Latin documents concerning the investigation of the rabbi for blasphemy, but his critique is clearly aimed at the broader interpretation presented in the article. However, his response was also explicitly polemical in tone. A careful reading of the Hebrew account in comparison with all of the relevant Latin texts, in Denifle's view, exposed the Hebrew account as a deliberate fabrication by Nahmanides intended to conceal the fact that he failed miserably in his task. In addition, he asserted that Graetz's interpretation was marred by the Jewish historian's failure to take account all of the sources or to accept the friars' interpretation of the Talmudic passages in question.

Not surprisingly, Heinrich Graetz and D. P. H. Denilfle both give voice to a representation of the past could have immediate implications politically and socially in the present. And the vitriol at the core of the exchange established both the event of the disputation and the texts that represent it as vital to a broader narrative of Jewish history. Building upon this example, twentieth-century historiography of the Jewish middle ages integrated a critical assessment of this event and both narrative accounts into the standard narrative of medieval Jewish history. Denifle and the early Jewish historians read inconsistencies or possible manipulation of details in the disputation texts as evidence that one or the other author willfully misrepresented the truth. In contrast, much of the scholarship produced during the twentieth century struggles to make sense of the truth claims of the Hebrew and Latin disputation accounts as a product of the historical time and place in which they were written. Consequently, the majority of the scholars writing in the twentieth and the twenty-first centuries deal with the challenges posed by possibly unreliable sources by considering the political, social, or religious context that might have inspired the author to represent the events as he did. 


\section{Text and Context}

Whereas early Jewish historians took pains not to cast Jewish documentary evidence in doubt for fear that acknowledging that Jewish authors may have embellished narratives might imperil the scholarly project, scholarship written in the second half of the twentieth century began taking stock of contingencies that directed the content and tone of Nahmanides' disputation narrative. In particular, in the effort to account for why Nahmanides wrote a disputation account that defied modern standards of exactingly accurate reportage, many have directed their attention either to questions related to the power dynamics at play for all participants in the disputation and Nahmanides' self-fashioning as a figure within Jewish intellectual, religious, and political life. At the base of these considerations are concerns about Nahmanides' motives. Nahmanides' detailed representation of the content and tone of debate, along with his claim that the king and friars granted him freedom of speech during the duration of the disputation, seem directly at odds with the friars' explicit goal in holding the disputation: to prove, using the Talmud as evidence, that the Jews had been misinterpreting rabbinic traditions about the messianic age and interpretations of historical events. Nahmanides' participation in the disputation-from his willingness to engage in a debate that, at least in retrospect, was clearly mired in danger, to his decision to share an avid defense of Jewish messianic expectation with Christian authorities-has sounded alarm bells for modern scholars who find it difficult to reconcile missteps in his approach to the disputation with the image of Nahmanides as a savvy leader, ardent protector of Jewish tradition, and innovative mystical exegete. At the base of many of these considerations is an effort to come to understand the political and religious motivations of Jewish leaders in a time that both permitted Jews considerable religious creativity and autonomy but also regulated them and occasionally interfered in the workings of the Jewish community. Nahmanides' arguments during the disputation and his effort to record the event resist classification as strictly protective of Jewish isolation and distinctiveness.

Martin Cohen's study of the political alliances that shaped this event made an early and important contribution to interpreting the politics behind Nahmanides' role in the disputation and its textual legacy (Cohen 1964). Cohen's approach to this event was rooted in political and institutional history embedded in a fairly neat (though unstated) taxonomy of power and obligation that assumes reliable motivations and behavior. His analysis rests on the assumption that all of the individual or corporate participants in the disputation jealously guarded political positions in a zero sum competition for advantage in a political economy that allowed nobody a clear upper hand and in which political circumstances determined actions. 
This approach leads to a close focus on the natural disadvantage Nahmanides suffered as a Jew defending his faith before Christian authorities and how weak his position shaped his actions during and after the disputation (Cohen 1964: 183-185). Granting that a Christian victory was guaranteed, Cohen set out to make sense of the motivations behind those who participated in the disputation and then later wrote the texts that preserve it in the historical memory. According to the Hebrew account, the Christian authorities granted Nahmanides freedom of speech:

Our lord the king commanded me to debate with Friar Paul before him and his council in his palace in Barcelona. I answered and said: 'I will do as you command, my lord king, if you give me permission to speak as I please. And I request in this matter the permission of the king and of Friar Ramon de Peñaforte and his colleagues who are here.' Friar Ramon (de Peñaforte) replied: 'Only if you do not speak contemptuously.' I replied to them: 'I do not want to subject myself to your judgment on this; I must speak as I please during the disputation just as you may say what you wish. As for me, I have [sufficient] wisdom to speak discretely. But I must speak as I wish.' They all granted me freedom to speak freely (Chavel 1964: 302-303)

This assertion is both key to the Hebrew disputation account and at the center of the controversy that followed its publication. Accepting at face value that Nahmanides' claim was true, Cohen sets out to examine what compelled the rabbi to write an account of the debate. He finds an answer in internal church power struggles: Nahmanides produced this work in response to a request from the bishop of Girona, who believed the rabbi's written account of the debate would provide leverage in a competition between the bishop and the increasingly powerful Franciscan friars (Cohen 1964: 188). Cohen's interpretation of Nahmanides' performance during and after the disputation also builds from his assumptions about what the rabbi would have thought based on his position as a representative of the Jewish community in the Christian Crown of Aragon. His willingness to participate in the disputation must then be understood first and foremost as a product of his political obligation to the king, not to the Jewish community. Cohen based his assumption that Nahmanides separated his loyalty and obligation to king from his responsibility as a leader in the Jewish community on Nahmanides' clear statement in the Hebrew account (and confirmed in the Latin account) first that he did not subscribe to the authority of an aggadic source, and then, that aggadic sources are primarily didactic and not binding.

I rose, saying: 'Hear me, all people' (Micah 1:2), Friar Paul asked me if the Messiah that the prophets talk about had already come, and I said he had not come. He brought a book of homilies (sefer aggadah) that says that he was born on the very 
day that the Temple was destroyed. And I said that I did not believe that, but that it was proof of my argument. Now I will explain to you why I said I did not believe that. [You should] know that we have three types of books. The first is the biblia and all of us believe it in its entirety. [Nahmanides transliterates the vernacular term, rather than using the Hebrew term, Torah, which includes the five books of Moses: the observation is mine.] The second is called the Talmud, and it explains the commandments of the Torah, for the Torah contains 613 commandments and not one of those is not explained in the Talmud. We accept it as an explanation of the commandments. Finally, we have a third body of literature that is called Midrash, that is to say, sermons. [Once again, Nahmanides presents a transliteration of the vernacular to introduce this body of commentary: also that observation is mine.] It is as if the bishop were to stand and give a sermon, and one of the audience found it pleasing and wrote it down. If one believes the content of this literature, then all the better; if one does not believe it, then no harm is done. So, we do have sages who wrote that the Messiah would not be born until the time of the end is near, then he will come to bring us from the galut (exile). Thus, I do not believe in the statement in the book that the Messiah was born on the day of the destruction. Moreover, we call this book Sefer Aggadah, which means Rasionamiento. That is to say, it is simply sayings that one person tells his friend (Chavel 1964: 308).

Viewing Nahmanides first and foremost as a representative of and advocate for the mystical school of kabbalah, Cohen saw a clear contradiction between the view of aggadah expressed in the disputation account and the view of aggadah widely held by other early kabbalists (Cohen 1964: 169-71). As such, in Cohen's view, Nahmanides' statements about aggadah demonstrate that the friar's arguments had pushed the rabbi into a rhetorical corner forcing him to deny that Jews were obliged to subscribe to the absolute authority of statements of this body of rabbinic literature.

Cohen's interpretation of Nahmanides' claim that aggadot are not universally binding is built upon a relatively well accepted and fairly static assumption that anyone who accepted mystical hermeneutics during the thirteenth century, in the wake of controversies over the nature of and threat posed by Maimonides' rationalist criticism of aggadah, would by definition subscribe to a broadly inclusive view that aggadic sources are binding and any suggestion to the contrary was tantamount to accepting a Maimonidean view of authority (Cohen 1964: 169). At the core of Cohen's argument is an implicit assumption that as an early kabbalist, Nahmanides would have categorically accepted the complete authority of aggadah. Marvin Fox convincingly challenged this assumption. In Fox's view 'the position expressed [by Cohen, Yitzhak Baer, and others] rests on a misconception of the nature of Jewish orthodoxy and, in particular, the orthodoxy of Nahmanides, who is classified as a more or less anti-rationalist kabbalist' (Fox 1990: 97). Prior to Fox, Bernard Septimus laid the foundation for a systematic reassessment of 
Nahamnides' approach to rabbinic authority and the role of rationality in his exegesis. However, Septimus' arguments were exclusively focused on Nahmanides' exegetical writing and did not take into account the arguments presented in the disputation account.

Also, seeking to move away from a methodology that classifies Nahmanides' arguments in the partisan terms of a contest between faith and reason, Fox proposed a more heuristic approach that considers the role of aggadic prooftexts in Nahmanides exegetical writings. Fox shifted the frame of analysis from Nahmanides' success and strategies as a representative of the Jewish community in the rarified context of a coerced polemical debate to the voice Nahmanides developed over the course of decades as a teacher and interpreter of scripture and rabbinic authority. Fox's argument that Nahmanides viewed aggadot contextually and critically throughout his interpretive works firmly situates the arguments expressed during the disputation in a context directly shaped by Jewish intellectual, cultural, and religious concerns. In direct contrast to the vast majority of scholars before him who examined the role of aggadah in Nahmanides' disputation account, Fox sees Nahmanides' discourse in the disputation as completely consistent with his other writings. In some sense, this approach takes a very different course than does the dominant scholarship, yet maintains some of the foundational assumptions of the dominant scholarship on the disputation. Nahmanides faced his marginalization of the polemical and political pressures during the disputation as the force shaping his arguments about the authority of aggadot and rules for interpreting these sources seems to be rooted in an acceptance of Nahmanides' claim that the friars and Christian authorities granted him freedom of speech. In this regard, Fox's reading of Nahmanides' disputation account accepts one of the central assumptions in much of the scholarship on the disputation. However, his emphasis on finding continuities between Nahmanides' exegetical and polemical methods and discourse in the disputation introduces to the analysis of the rabbi's performance in the disputation some relatively novel assumptions about the rabbi. The most significant of these is the assumption that Nahmanides spoke with the same interpretive and political voice, whether addressing a Christian or Jewish audience.

Questions about whether Nahmanides' public performance in the disputation and the textual narrative represented views he might have expressed in his role as leader and teacher in the community also play a foundational role in Robert Chazan's transformative work, Barcelona and Beyond: The Disputation of 1263 and Its Aftermath (Chazan 1992). Whereas Fox mobilized evidence of Nahmanides' consistent commitment to specific exegetical norms to counter claims that the rabbi's arguments emerged from fear rather than conviction, Chazan turned his attention to the public persona 
Nahmanides presented to Jewish and Christian audiences during his public performance and his written account. Cautious not to fall into the trap of mistaking the written accounts of the disputation for accurate reports of how the debate unfolded, Chazan's study focuses instead on questions about how the accounts served the broader political and theological interests of both authors (Chazan 1992: 80-141). His approach is systematic and methodical. He carefully disaggregated the event itself from the documents recording it, treating them in separate chapters and the products of distinct causes. In keeping with Yitzhak Baer, Cecil Roth, and Martin Cohen, Chazan emphasized that the circumstances of the disputation forced Nahmanides into a position that demanded that he dissimulate his views and interpretations in order to forestall the imposition of persistent and active Christian oversight over Jewish practice and literature. But because he had the luxury of presenting his analysis of the disputation and its documentary remains in a full length monograph, rather than shorter form journal articles, Chazan was able to draw out systematically and in minute detail his understanding of the friars' goals, the dangers they posed to the Jewish community and to Nahmanides personally, as well as the strategies Nahmanides employed to protect the Jewish community from a polemical tactic he perceived as potentially very powerful and therefore potentially very threatening.

Both Chazan's methodical and comprehensive analysis and his conclusions about why Nahmanides' circulated a first-hand account of the disputation were instrumental in shifting the terms of discussion. Chazan argues that Nahmanides preserved and circulated the arguments he made in the course of the disputation to provide readers with a successful refutation of a new and profoundly threatening, if not overtly damaging, missionizing strategy on the part of the friars (Chazan 1992: 18-27). Having conducted a review of Nahmanides' later works, Chazan concludes that the rabbi spent the final years of his life trying to render the friars impotent in their effort to undermine Jewish faith and rabbinic textual authority. Like Martin Cohen before him, Chazan appears to be driven by a desire to reconcile Nahmanides' actions during and following the disputation (including the fact that he circulated his account) with what the accepted historical narrative has represented as a period of gradually shifting attitudes towards Jews and Judaism within the Church. While completely solid in its evidence and logic, Chazan's analysis focuses on one facet of Nahmanides' role as a leader in the Jewish community, while opting not to explore the position Nahmanides and the Jewish community held in Catalan society and culture as a whole.

Chazan's study is the first work of systematic scholarship to assess the literary value of Nahmanides' account. He argues that the Latin disputation 
account, which represents the rabbi's speech as severely constrained, offers the more plausible representation of the debate (Chazan 1992: 123-124). Having concluded that portions of Nahmanides' account are obviously fictitious, he is left wondering what might have moved Nahmanides to consciously misrepresent the true nature of the disputation (Chazan 1992: 100141). Many of the scholars Chazan was responding to also read the Hebrew disputation narrative as a less than accurate account either intended to compensate for a job poorly done or to smooth over political tensions. But adding an additional layer of nuance to the conclusions drawn by previous scholars, Chazan undertook to examine what purpose exaggerated or fictionalized reports in the Hebrew account served. Based on a careful assessment of the friars' missionizing campaigns along with his close comparison between the arguments as presented in the Hebrew and Latin disputation accounts. Chazan concluded that the rabbi embellished a good deal the speech in his account in an attempt to provide a model response and antidote to the Dominicans' aggressive new effort to convert Jews to Christianity. He argued that Nahmanides crafted this fictionalized account with a twofold purpose: first to reassure Jews that their messiah was still to be expected, and secondly to provide a working example of an effective response to the friars' line of argument. '[W]hile the portrait of Nahmanides the debater may be somewhat exaggerated [in the Hebrew document], the skills of Nahmanides the narrator and polemicist are outstanding' (Chazan 1992: 140). Chazan, then, established separate spheres for the study of the Hebrew disputation account as historical fact and polemical tract. The former, he suggested, falls in the domain of Jewish literature, while the latter is more appropriately grouped in the frame of Jewish leadership.

\section{The Rhetoric of History}

Chazan's approach to the Barcelona disputation and the textual records that describe it had a significant influence on a relatively sizable group of scholars who embraced the conclusion that Nahmanides carefully crafted his disputation account as a literary work, and not an entirely faithful report of the events as they unfolded. In a recent essay, Harvey Hames has used the Hebrew disputation account as a source for examining the degree to which the views Nahmanides expressed in his exegesis carried over to his actions as a mediator between the Jewish community and Christian authorities. The Hebrew disputation account, Hames argues, provides important evidence for Nahmanides' perception and understanding of royal authority. In particular, Nahmanides' representation of his relationship with King James I reveals both mutual respect between the rabbi and the king and his fundamental understanding, laid out in his biblical exegesis, of the nature of kingship in general. He argues that Nahmanides presents himself and the king as near equals, while his representation of the friars' behavior 
makes them appear almost as interlopers. According to Hames, the rabbi's depiction of his relationship and exchanges with the king as well as the king's ability to exercise authority in the disputation account reflected Nahmanides' political philosophy. In keeping with his exegetical tendency to seek out typologies as meaningful and predictive, Hames argues, Nahmanides' interpretation of Abraham's interactions with Nimrod in Genesis 10 indicates that he viewed kings as the holders of supreme earthly power, whether or not they used that power for good. Nahmanides' representation of his own relationship with King James as a positive one based largely on mutual respect might then be read as a product of this typological model, one in which he emerged as the typological parallel with Abraham. If so, Hames suggests, then Nahmanides' understanding of typology and causality may have played a role in the shape and narrative structure of his disputation account.

The influence of Chazan's approach is also evidenced in my own work on the disputation narrative. Using Chazan's observation that Nahmanides self consciously fictionalized or embellished parts of the disputation account as a point of departure, I have focused on three central issues in the narrative: how Nahmanides figured acceptable and unacceptable expressions of Jewish power and authority in a Christian context, how Nahmanides represented Paul as a convert, and finally, how Nahmanides' position among the intellectual elite of Catalonian Jewry found expression in the disputation account, and particularly in his possible authorship of a work of Catalan literature under the patronage of the bishop of Girona. Along with most of my contemporaries, I used H. D. Chavel's edition as my source, though its shortcomings remain quite apparent, because it is well known and widely accessible. But a turn in the recent scholarship on the disputation toward manuscript criticism of Nahmanides' text has both provided welcome support for some of my conclusions and pushed me to begin rethinking some of my arguments about the construction of the text. ${ }^{2}$

The printed edition of Nahmanides' Hebrew disputation account opens with a frame narrative quote from the Babylonia Talmud, Sanhedrin 43a, which describes the trial and execution of 5 of Jesus's disciples in a rabbinic court. I have read this opening preamble as an explanation provided by Nahmanides to his reader for why his debate with Friar Paul merited preservation (Caputo 2007: 107-110). The friar had converted to Christiani-

2 Ursula Ragacs is conducting a systematic study of the manuscript tradition in the hope of striping away additions and changes imposed on the text as it was copied and recopied over the generations. Piero Capelli laments the lack of critical editions and suggests that this gap in the scholarship is the product of cultural and political factors in postemancipation Germany that stymied the development of medieval Hebrew philology among the scholars of the Wissenschaft des Judentums movement. 
ty and used his new access to Christian power to challenge Jewish religious and political autonomy. Consequently, his arguments merited response. Whether Nahmanides himself opened the text with this preamble has been the subject of some scholarly contention. Hyam Maccoby has argued that due to the highly controversial nature of the passage, it must have been tacked onto Nahmanides' original text at some later date (Maccoby 1982: 97-101). Others have suggested that inconsistencies between versions of the preamble as it appears in various manuscript editions may indicate scribal error or a misinterpretation of Nahmanides' arguments by an early copyists (Chazan 1980: 105-106; Ragacs 2015: 102-107; for an argument to the contrary, which points to the earliest full manuscript edition of Nahmanides' account as evidence that he did open his narrative with this text, see Hames 2014: 10). The fact that the opening passage of Nahmanides' account was apparently subject to significant modification and revision, whether intentional or accidental, over the centuries does necessitate careful source criticism of the standard edition. Hames' analysis of Nahmanides' conceptualization of royal authority in the disputation account helps flesh out a significant theme in the rabbi's text that provides a coherent thread that run from the beginning of the narrative to the end. The preamble also helps make sense of Nahmanides' representation of and responses to various Christian beliefs in the disputation. His depiction of Friar Paul as harmful and hostile focuses on the friar's use of rabbinic sources. The friar, then, represents all of the worst qualities of a convert-the same hostile qualities for which passage from Sanhedrin calls for the punishment of the apostles. In contrast, Nahmanides represents the king and others who were born Christian as misguided, but not fundamentally malevolent.

Investigation into how Nahmanides' text both contributed to and emerged from a growing body of literature in the Catalan vernacular is also born of the effort to read Nahmanides' account as a highly constructed work. The role of the vernacular in the disputation and in the texts recording it has received relatively little scholarly attention. Questions about which language Nahmanides spoke during the disputation and in which language he chose to write his account are quite important because they shed light on how well the rabbi was able to communicate with his adversaries and make sense of the nuances and subtleties of theological arguments. Nahmanides likely wrote at least two versions of this account; one in Hebrew for a Jewish audience, and another as a gift to the bishop of Girona, most likely in Catalan, which no longer remains. The two texts, distinct but likely not unrelated, represent the author's engagement in the politics, aesthetics, and rhythms of the respective languages and their literatures. Since the version given to the bishop is no longer available, though, any analysis of how Nahmanides' language of composition effected the content or shape of the 
narrative must rely on the Hebrew document alone. That Nahmanides' text both contributed to and emerged from a growing body of literature in the Catalan vernacular is apparent in the Hebrew document itself.

Nahmanides' Hebrew account contains several transliterated vernacular terms. A good number of those are personal or place names (Bianchi 2005: 407-412; Casanellas 2014). But several render commonplace terms, including day and bible, in transliterated from. In one notable case, midway through the description of the second day of debate at the Barcelona disputation, Nahmanides interrupted the flow of dialogue and narrative to introduce a surprising narrative digression. The argument here revolves around whether the Hebrew word yom, or day, must be interpreted literally or symbolically in the prophecy of Daniel. To resolve the disagreement between Nahmanides and the friar, an attendant is told to bring a Jew in off the street.

Friar Paul said that there is no Jew in the world who would not agree that the meaning of 'yom' is a real day unless he changes (the meaning of words) according to his desire.

He shouted to the king, so they brought a Jew, the first they found, and asked him: 'What does yom (day) mean in your language?' He said: 'Day' (Chavel 1964: 314)

Nahmanides' disputation account is richly adorned with stylistic and substantive clues that show him as an author navigating two connected, though distinct political and cultural arenas. To establish his own domain of authority during the disputation debate Nahmanides exhibited a command of the sources and master narrative of Jewish history and scriptural interpretation. The substance, style, and structure of his disputation account attest to a mastery of the aesthetic and structural demands of contemporary literary production and historical narrative as well. Pere Casanellas has argued that the transliteration of personal and place names is a strong indication that the author may have written the text in Catalan then translated it into Hebrew. But the fact that Catalan literature of the time, most notably King James' Llibre dels Fets or Book of My Deeds, makes similar use of Arabic words may suggest that the careful deployment of vernacular words may have been a stylistic flourish, as well as a means of presenting information to a reading audience that shared a local vocabulary.

Recent scholarship on Nahmanides' participation in the Barcelona disputation and the textual evidence related to this event has, in some respects, come full circle back to fundamental questions about the reliability of the sources and the stories they tell. Unlike early source criticism by Denifle and others, the emphasis in recent scholarship focuses on scribes as the 
agents of textual corruption, rather than Nahmanides as an untrustworthy reporter. This approach provides new and very promising possibilities. For example, source criticism, such as the one Ursula Ragacs is undertaking, will make viable a more systematic reception history of the Hebrew disputation narrative that takes into account where and when amendments to the text may have been introduced, possibly laying the foundation for investigations into how political and religious circumstances may have shaped the way readers processed the narrative Nahmanides provided.

\section{Bibliography}

Assis YT (1997) The Golden Age of Aragonese Jewry: Community and Society in the Crown of Aragon, 1213-1327. London: The Littman Library of Jewish Civilization.

Bianchi F (2005) The Hebrew Language of the Disputation of Barcelona. Actes del II Congrés per a l'Estudi dels Jueus en Territoris de Llengua Catalana, pp. 407-412.

Capelli P (2015) Editing Thirteenth-Century Polemical Texts: Questions of Method and the Status Quaestionis in Three Polemical Works, Henoch 37(1): 43-52.

Caputo N (2007) Nahmanides in Medieval Catalonia: History, Community, and Messianism. Notre Dame: University of Notre Dame Press.

Casanellas P (2014) Noms propis i altres mots catalans en el relat en Hebreu de la Disputa de Barcelona de 1263 entre fra Pol Cristià i Rabí Mossé ben Nahman. Tamid 10(1): 125-45.

Chavel HD (1959) Perush ha-Ramban al ha-Torah, volume 1-2. Jerusalem: Mosad ha-Rav Kook.

Chavel HD (1964) Vikuah ha-Ramban. In Kitvei Rabbenu Moshe ben Nahman $1(*)$ : 302-20. Jerusalem: Mosad ha-Rav Kook.

Chazan R (1992) Barcelona and Beyond: The Disputation of 1263 and Its Aftermath. Berkeley and Los Angeles: University of California Press.

Chazan R (1980) A Medieval Hebrew Polemical Mélange. Hebrew Union College Annual 51(*): 89-110.

Cohen J (1982) The Friars and the Jews: The Evolution of Medieval Anti-Judaism. Ithaca: Cornell University Press.

Cohen J (1987) The Mentality of the Medieval Jewish Apostate: Peter Alfonsi, Hermann of Cologne, and Pablo Christiani. In Endelman T (ed) Jewish Apostasy in the Modern World. New York: Holmes and Meier, pp. 20-47.

Cohen MA (1964) Reflections on the Text and Context of the Disputation of Barcelona. Hebrew Union College Annual 35(*): 157-92.

Denifle DPH (1887) Quellen zur Disputation Pablos Christiani mit Mose Nachmani zu Barcelona 1263. Historisches Jahrbuch 8(*): 225-44. 
Fox M (1989) Nahmanides on the Status of Aggadot: Perspectives on the Disputation at Barcelona, 1263. Journal of Jewish Studies 40(1): 95-109.

Funkenstein A (1971) Basic Types of Anti-Jewish Polemics in the Later Middle Ages. Viator 2(*): 373-82.

Graetz H (1865) Die Disputation des Bonastruc mit Frai Pablo in Barcelona. Monatsschrift für Geschichte und Wissenschaft des Judenthums 14(12): 428-33.

Hames HJ (2015) Reconstructing Thirteenth-Century Jewish-Christian Polemic: From Paris 1240 to Barcelona 1263 and Back Again. In Szpiech R (ed) Medieval Exegesis and Religious Difference: Commentary, Conflict, and Community in the Premodern Mediterranean. New York: Fordham University Press, pp. 115-127

Hames HJ (2014) 'Fear God, My Son, and King': Relations between Nahmanides and King Jaime I at the Barcelona Disputation. Hispania Judaica Bulletin 10: 5-19.

Hames HJ (2004) Reason and Faith: Inter-Religious Polemic and Christian Identity in the Thirteenth Century. In Krech V and Schwartz Y (eds) Religious Apologetics-Philosophical Argumentation. Tübingen: Mohr Siebeck, pp. 267-284.

Maccoby H (1982) Judaism on Trial: Jewish-Christian Disputations in the Middle Ages. London: Associated University Presses.

Ragacs U (2015) Reconstructing Medieval Jewish-Christian Disputations. In Szpiech R (ed) Medieval Exegesis and Religious Difference: Commentary, Conflict, and Community in the Premodern Mediterranean. New York: Fordham University Press, pp. 101-112.

Ragacs U (2011) Christian-Jewish or Jewish-Jewish, That's My Question... European Journal of Jewish Studies 5(1): 93-114.

Ragacs U (2009) Edieren oder nicht edieren...?: Überlegungen zu einer Neuedition des hebräischen Berichtes über die Disputation von Barcelona 1263. Teil 2: Dei Hanschriften. Judaica 65(3): 239-58.

Ragacs U (2006) Edieren oder nicht edieren...? : Überlegungen zu einer Neuedition des hebräischen Berichtes über die Disputation von Barcelona 1263. Judaica 62(2): 157-170.

Riera i Sans J (1985) Les fontes històriques de la Disputa de Barcelona. In Feliu E (ed) Disputa de Barcelona de 1263 Entre Mestre Mossé de Girona i Fra Pau Christià. Barcelona: Columna Edicions, pp. ix-xv.

Septimus B (1983) Open Rebuke and Concealed Love: Nahmanides and the Andalusian Tradition. In Twersky I. Rabbi Moses Nahmanides (Ramban): Explorations in His Religious and Literary Virtuosity. Harvard University Center for Jewish Studies: Texts and Studies. Cambridge, MA: Harvard University Press, pp. 11-34.

Wagenseil JC (1681) Tela ignea Satanae: Hoc est, arcani, et horribiles Judaeorum

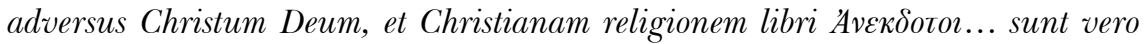


R. Lipmanni Carmen memoriale, Liber Nizzachon vetus autoris incogniti; Acta disputationis R. Jechielis cum quodam Nicolao; Acta disputationis R. Mosis Nachmanidis cum fratre Paulo Christiani, et fratre Raymundo Martini; $R$. Isaaci Liber Chissuk Emuna ; Libellus Toldos Jeschu Altdorfi Noricorum. 